\title{
Sportsmanship and basic psychological needs in sports students
}

Authors' Contribution: A Study Design B Data Collection C Statistical Analysis D Data Interpretation E Manuscript Preparation F Literature Search G Funds Collection

\author{
Germina-Alina Cosma 1,2 ADE , Alina Chiracu3 ACD , Amalia-Raluca Stepan ${ }^{1}$ ACD, \\ Roxana Gatzel ${ }^{2 B F}$, Augustin lancu ${ }^{2}$ BF, Alexandru Cosma ${ }^{1}$ ACDF \\ ${ }^{1}$ Faculty of Physical Education and Sport, University of Craiova, Craiova, Romania \\ 2 Doctoral School of Social Sciences and Humanities, University of Craiova, \\ Craiova, Romania \\ ${ }^{3}$ Faculty of Psychology and Educational Sciences, University of Bucharest, \\ Bucharest, Romania
}

\section{abstract}

Background: The aim of this study was to examine the relationships among satisfaction of basic psychological needs, goal orientations and sportsmanship.

Material and methods:

The mediating role of goal orientation in this relationship was tested. The participants were 168 students enrolled at the Faculty of Physical Education and Sports in Craiova, aged between 18 and 30 years old, $M=21.52, S D=2.20$, and the data were collected between March and May 2020. The instruments applied were Basic Psychological Needs Satisfaction Scale to measure satisfaction of basic psychological needs, Multidimensional Sportspersonship Orientation Scale to measure sportsmanship, and Ego and Task Orientation Questionnaire to measure goal orientation.

Results: The obtained results showed that the satisfaction of basic psychological needs is associated with sportsmanship. Mediation analyses have shown that task orientation mediates the relationship between the need for autonomy and the need for competence satisfaction and four of the dimensions of sportsmanship and the relationship between the need for relatedness satisfaction and three of sportsmanship dimensions: respect for social conventions, respect for rules and officials, and respect for full commitment.

Conclusions: Thus, based on these results, specific training programs can be developed that focus on developing the intrinsic motivation of athletes and task orientation in general. Attitude formation, on which the character is structured and developed, implies specific methods and techniques that can be developed through training.

Key words: basic psychological needs, sportsmanship, goal orientation, sports students.

\section{article details}

Article statistics: Word count: 4,844; Tables: 5; Figures: 0; References: 60

Received: June 2021; Accepted: October 2021; Published: November 2021

Full-text PDF: http://www.balticsportscience.com

Copyright @ Gdansk University of Physical Education and Sport, Poland

Indexation: Celdes, Clarivate Analytics Emerging Sources Citation Index (ESCI), CNKI Scholar (China National Knowledge Infrastructure), CNPIEC, DOAJ, EBSCO - Central \& Eastern European Academic Source, EBSCO - SPORTDiscus, EBSCO Discovery Service, Google Scholar, Index Copernicus, J-Gate, Naviga (Softweco, Primo Central (ExLibris), ProQuest - Family Health, ProQuest - Health \& Medical Complete, ProQuest - Illustrata: Health Sciences, ProQuest Nursing \& Allied Health Source, Summon (Serials Solutions/ProQuest, TDOne (TDNet), Ulrich's Periodicals Directory/ ulrichsweb, WorldCat (OCLC)

Funding: This research received no specific grant from any funding agency in the public, commercial, or not-for-profit sectors.

Conflict of interests: Authors have declared that no competing interest exists.

Corresponding author: Germina-Alina Cosma; Faculty of Physical Education and Sport, University of Craiova; email: germinacosma@ yahoo.com

Open Access License: This is an open access article distributed under the terms of the Creative Commons Attribution-Non-Commercial-NoDerivatives 4.0 International (https://creativecommons.org/licenses/by-nc-nd/4.0/), which permits use, distribution, and reproduction in any medium, provided the original work is properly cited, the use is non-commercial and is otherwise in compliance with the license. 


\section{INTRODUCTION}

\section{BASIC PSYCHOLOGICAL NEEDS IN ATHLETES}

The theory of basic psychological needs refers to three fundamental needs: autonomy, competence, and relatedness. The need for autonomy is satisfied when a person feels in control of his own actions; the need for competence is satisfied when a person realizes that he successfully masters the environment and interactions, and the need for relationships is satisfied when a person feels connected with others, feels understood and can understand those around him [1]. Meeting the three basic psychological needs is essential for human development and functioning [2].

When these three basic psychological needs are met in a sports context, it is assumed that athletes' well-being and motivation will improve [3]. Numerous studies have shown that meeting basic psychological needs is associated with physical activity intentions $[4,5]$ or performance [6], but there are not enough studies to show the links between meeting basic psychological needs and sportsmanship [7].

An environment that facilitates the fulfilment of basic psychological needs, namely competence, autonomy and relatedness creates an autonomous and motivated individual [8]. These, in turn, are positively associated with prosocial behaviour and negatively associated with antisocial behaviour [9].

According to the theory of self-determination, when psychological needs are obstructed, two possible consequences arise. First of all, people pay the immediate price by dramatically reducing their well-being. Secondly, when satisfaction of needs is chronically hindered, people develop certain coping strategies to accommodate the experience of need frustration, which translates into the development of need substitutes and involvement in compensatory behaviours $[10,11]$.

Cross-sectional studies have shown that need satisfaction is associated with a lower level of exhaustion among employed adults [12,13], with a lower level of anger and anxiety among teachers [14] and with fewer teacher-student relationship problems among adolescents [15]. Moreover, studies based on daily journals have shown that daily increases and decreases in psychological need satisfaction are associated with daily fluctuations in symptoms and adverse effects among students [16, 17] and among employed adults [18, 19]. On the other hand, frustration of psychological needs has been associated with decreased well-being in athletes [20, 21] and coaches [22]. Frustration of psychological needs has also been associated with increased levels of S-IgA, an immunological protein responsible for anticipating acute stressors [21].

Joussemet conducted a study related aggressive behaviour with satisfaction threat of need for autonomy during the school years [23]. After keeping under control the risk factors for aggression (male gender, reactive temperament, separated or divorced parents), the authors observed that parenting based on high maternal control is a robust predictor of aggressive behaviour.

Persistent experimentation with the frustration of psychological needs endangers people's sense of security, causing them to look for external indicators of their significance and thus setting extrinsic goals. Studies show that those children without support and affection within the family are more likely to seek and value extrinsic goals [24].

It is important to note that although extrinsic goals may be attractive, they only confer a transient state of satisfaction and in the long run interfere with genuine satisfaction of needs and well-being [25]. High investment in extrinsic goals is associated with a range of intrapersonal consequences, such as anxiety, physical symptoms and drug use, but also with 
interpersonal, intrinsically oriented people proving higher levels of Machiavellianism, being competitive rather than collaborative and manifesting more aggressive and discriminatory attitudes toward others [26].

In addition to association with internalized problems (anxiety, depression), the rigid patterns of behaviour are a form of compensation for the frustration of basic psychological needs. They are also associated with moral functioning, in the sense that individuals who choose such behaviours go a long way in achieving their ambitions, even at the cost of health or ethics. Vansteenkiste showed that footballers rigidly oriented to defeat opponents are more likely to show acts of aggression and get more yellow and red cards [27]. Moreover, controlled motivation for sports decreases the spirit of competition and increases the consumption of energizing substances [28].

While rigid patterns of behaviour are ways to internalize problems, provocative oppositionism is the basic mechanism in the aetiology of externalized problems. It implies marked resistance to involvement in certain activities and reflects a type of controlled regulation [29]. Specifically, provocative oppositionism is a reaction to control and is often associated with detachment from significant people and refusal of guidance from them [30].

Provocative oppositionism and forms of compliance based on external pressure are different sides of the same coin, because when exposed to an environment that prevents them from meeting their needs, individuals oscillate between capitulating for control reasons or defying authority figures. Studies have shown that the prohibitions imposed by parents on children, which are perceived as having a high degree of control, are significant predictors of provocative oppositionism [31]. Other studies have highlighted the explanatory role of basic psychological need frustration in the relationship between control-based parenting, provocative oppositionism, and associated behavioural problems [32].

\section{SPORTSMANSHIP AND GOAL ORIENTATION}

Sportsmanship is hard to be defined with clarity. The National Collegiate Athletic Association [33] defined sportsmanship as the set of behaviours to be exhibited by athletes, coaches, officials, administrators and fans in athletic competitions. These behaviours are based on such fundamental values as respect, fairness, civility, honesty, and responsibility.

Shields and Bredemeier considered sportsmanship as the virtue of coordinating the game with the competition in light of moral goals [34]. Sportsmanship has been defined as behavioural tendencies that determine how all individuals involved in sporting activities will behave in keeping with the spirit of sport [35], or as moral attitudes and behaviours in sport [36]. Sport ethics refers not only to the respect for the rules of the game, but also to the ability to show respect to opponents without giving up the desire to win and to show a fair and honest attitude [37]. According to the Olympic ideal, the essence in sport is not to win, but to participate [38].

The competition is closely related to sportsmanship. Specialists distinguish two types of competition orientation - ego orientation and task orientation. Individuals driven by ego orientation choose to compete to defeat their opponents. By winning, they seek to assert themselves and expose their superiority. To win, all means are put into battle, at all costs, including immoral ones (cheating or hurting the opponents). Individuals driven by task orientation do not focus on winning, but on accomplishing tasks. They enter competitions to improve their skills; the competition becoming more of a struggle with themselves, they focus on setting personal performance goals that are part of bigger and more important goals. Studies have shown that both orientations are present simultaneously in individuals, although the relative degree of each is different [39]. 
When ego orientation dominates, sportsmanship diminishes, especially in the context in which the idea of competition is exacerbated and young athletes are trained to win at any cost. Research shows that ego orientation is more common in young athletes. A study by Raspberry showed that $84 \%$ of young footballers intentionally fouled an opponent to prevent him from scoring a goal [40].

Regarding moral development in sport, a distinction must be made between moral education in general, as the intentional and deliberate activity of cultivating moral growth and moral judgment [41], and moral training, which involves compliance with the rules and social needs of a particular group. Social cognitive theorists argue that moral development is a result of the process of internalizing behaviours modelled and reinforced by significant adults, such as parents, coaches, teachers, or colleagues [42]. Subsequently, Bandura emphasized the reciprocal nature of the relationships between individual differences (affective reactions), environmental influences (group norms), and past moral behaviours [43]. Because morality is socially defined in certain societies, cultures, groups, clubs, the perceived motivational climate offered by sports, sports clubs, coaches, parents and teachers have a significant influence on the moral behaviour of athletes.

Rest and his colleagues proposed a four-component model of processes that influence moral reasoning, moral thought, and moral action [44]. The first component, moral sensitivity, involves the use of empathy and role-taking skills to accurately identify a situation as moral or not. The second component, moral judgment, involves choosing that course of action that is morally correct. The third component, moral motivation, involves evaluating the importance of the chosen action compared to different competing values. The fourth component, moral character, involves the implementation of a moral plan of action, based on reasoning and intent. This theoretical model emphasizes the reciprocal nature between each of the four components, but also the influence that coaches and instructors have in shaping sports environments which are then sources of learning moral skills for young athletes.

Bredemeier and Shields applied Rest's model in a sports context, introducing new components: the influence of personal skills, such as role-taking ability, moral-reasoning stage, achievement goal orientation and social problem solving skills. The influence of social factors such as goal structure, moral atmosphere, motivational climate, power structure, but also the influence of ego-processing variables such as empathy, logical analysis, sublimation, and concentration is also highlighted [45-47].

\section{MATERIAL AND METHODS}

Taking into account the above, the present study aims to investigate the relationships between basic psychological needs and sportsmanship. Moreover, the mediating role of goal orientation in this relationship will be tested. Thus, we formulated the following hypotheses: H1. Basic psychological needs satisfaction positively predicts sportsmanship.

H2. Goal orientations mediate the relationship between basic psychological needs satisfaction and sportsmanship.

\section{PARTICIPANTS AND PROCEDURE}

The participants were 168 students enrolled at the Faculty of Physical Education and Sports in Craiova, aged between 18 and 30 years old, $\mathrm{M}=21.52$, $\mathrm{SD}=2.20$, of which 74 males (44\%) and 94 females (56\%), 47 were in their first year (28\%), 65 in the second year (39\%), 29 in the third year (17\%), eight in their first year of master's studies (5\%), and 19 in their second year of master's studies (11\%). A total of $100(60 \%)$ practised individual sports and 41 (40\%) practised team sports. Regarding marital status, 88 were single (53\%), 64 were in a relationship (38\%), and 16 were married (9\%). 
The data were collected between March and May 2020. Participants were invited to participate in the research during their online faculty courses. Out of a total of 300 students, only 168 showed their intention to participate. The questionnaires were distributed in Google Forms via email addresses. The first section of the form contained the informed consent and the agreement to the processing of personal data. Completing the questionnaires took about 20 minutes. The approval of the Ethics Commission of the University was obtained.

\section{INSTRUMENTS}

Basic psychological need satisfaction was measured with the Basic Psychological Needs Satisfaction Scale $[28,48]$. The scale was developed by adapting a scale to measure the satisfaction of basic psychological needs in the workplace. The tool comprises 21 items organized in three subscales, autonomy, competence and relatedness. The answers are given on a seven-step Likert scale where 1 - not at all true and 7 - very true. The higher the scores are, the more satisfied the need is. Examples of items: "People in my life care about me", "In general I feel free to express my ideas and opinions".

Sportsmanship was measured with the Multidimensional Sportspersonship Orientation Scale, MSOS [49]. The instrument assesses five different types of sportspersonship orientations, respectively: concern and respect for the opponent, for rules and officials, for one's engagement in sport, for social conventions, and negative orientation towards sport participation. It contains 25 items, five for each subscale and is being assessed on a five-step Likert scale where 1 - does not correspond to me at all and 5 - corresponds to me exactly. Examples of items: "When I lose, I congratulate the opponent whoever he or she is" or "I really obey all rules of my sport".

Goal orientation was measured with the Ego and Task Orientation Questionnaire, TEOSQ. The instrument comprises 13 items, six for Ego orientation and seven for task orientation and is assessed on a five-step Likert scale where 1 - strongly disagree and 5 - strongly agree. Examples of items: "I feel most successful in sport when... I can do better than my friends" or "I learn a new skill by trying hard".

\section{RESULTS}

\section{DESCRIPTIVE STATISTICS}

Means, standard deviations, reliability coefficients and variable correlations are presented in Table 1.

Table 1. Means, standard deviations, reliability coefficients and variable correlations

\begin{tabular}{|c|c|c|c|c|c|c|c|c|c|c|c|c|c|}
\hline & M & SD & $\alpha$ & EO & TO & AS & CS & RS & $\mathrm{RSC}$ & RRO & RFC & ROP & NAS \\
\hline EO & 2.82 & .84 & .85 & 1 & & & & & & & & & \\
\hline TO & 4.41 & .52 & .78 & $.21 * *$ & 1 & & & & & & & & \\
\hline AS & 32.80 & 4.13 & .62 & .10 & $.44^{* *}$ & 1 & & & & & & & \\
\hline CS & 28.06 & 4.30 & .67 & .05 & $.41^{* *}$ & $.69 * *$ & 1 & & & & & & \\
\hline RS & 35.89 & 5.00 & .71 & .07 & $.45^{* *}$ & $.57 * *$ & $.64^{* *}$ & 1 & & & & & \\
\hline RSC & 21.11 & 3.51 & .72 & .07 & $.46^{* *}$ & $.20 *$ & $.24^{* *}$ & $.39 * *$ & 1 & & & & \\
\hline RRO & 21.01 & 3.12 & .72 & .04 & $.35^{* *}$ & $.24 * *$ & $.29 * *$ & $.29 * *$ & $.51^{* *}$ & 1 & & & \\
\hline RFC & 23.03 & 2.43 & .67 & $.20 *$ & $.54 * *$ & $.20 * *$ & $.24^{* *}$ & $.25^{* *}$ & $.45^{* *}$ & $.46^{* *}$ & 1 & & \\
\hline ROP & 18.07 & 4.04 & .72 & .03 & $.22^{* *}$ & .10 & .11 & $.27^{* *}$ & $.54 * *$ & $.39 * *$ & $.22^{* *}$ & 1 & \\
\hline NAS & 14.42 & 2.96 & .70 & $.24 * *$ & .06 & -.14 & -.13 & -.06 & -.04 & $-.19 *$ & .14 & .06 & 1 \\
\hline
\end{tabular}




\section{HYPOTHESES TESTING}

H1. Basic psychological needs satisfaction positively predicts sportsmanship.

In order to test this hypothesis, we ran a series of multiple linear regressions with autonomy satisfaction, competence satisfaction, relatedness satisfaction as predictors and the five dimensions of sportsmanship as dependent variables, using IBM SPSS 24 [50].

Table 2. Multiple linear regression analyses for basic psychological needs satisfaction predicting sportsmanship

\begin{tabular}{lllllllll}
\hline IV & DV & F & R2 & B & SE & $\beta$ & $t$ & $p$ \\
\hline AS & RSC & 9.65 & .15 & -.03 & .09 & -.04 & -.36 & .72 \\
CS & RSC & & & .01 & .09 & .01 & .04 & .97 \\
RS & RSC & & & .28 & .07 & .40 & 4.20 & .00 \\
AS & RRO & 6.25 & .10 & .04 & .08 & .05 & .44 & .66 \\
CS & RRO & & & .10 & .08 & .14 & 1.26 & .21 \\
RS & RRO & & & .11 & .06 & .17 & 1.76 & .08 \\
AS & RFC & 4.26 & .07 & .02 & .06 & .04 & .38 & .70 \\
CS & RFC & & & .06 & .07 & .11 & .94 & .35 \\
RS & RFC & & & .08 & .05 & .16 & 1.55 & .12 \\
AS & ROP & 4.62 & .08 & -.04 & .10 & -.04 & -.36 & .72 \\
CS & ROP & & & -.07 & .11 & -.08 & -.69 & .49 \\
RS & ROP & & & .27 & .08 & .34 & 3.38 & .00 \\
AS & NAS & .02 & 1.27 & -.08 & .08 & -.11 & -.96 & .34 \\
CS & NAS & & & -.07 & .08 & -.10 & -.81 & .42 \\
RS & NAS & & & .04 & .06 & .06 & .61 & .55 \\
\hline
\end{tabular}

AS - Autonomy satisfaction, CS - Competence satisfaction, RS - Relatedness satisfaction, RSC - Respect for social conventions, RRO Respect for rules and officials, RFC - Respect for full commitment, ROP - Respect for opponent, NAS - Negative approach toward sport

It can be seen that only the need for relatedness satisfaction is a significant positive predictor of some of the dimensions of sportsmanship, namely respect for social conventions, $\beta=.40$, $\mathrm{t}(168)=4.20, \mathrm{p}<.01$ and respect for opponents, $\beta=.34, \mathrm{t}(168)=3.38, \mathrm{p}<.01$.

H2. Goal orientations mediate the relationship between basic psychological needs satisfaction and sportsmanship.

In order to test this hypothesis, we ran a series of mediation analysis, using medmod module of Jamovi [51] (The jamovi project, 2021). Baron and Kenny suggested that a mediation model should not be tested unless there is a significant relationship between the predictor and the dependent variable [52], but in more recent treatments of mediation, it has been pointed out that there can be significant mediated effects even when the predictor and the dependent variable are not significantly correlated [53].

However, we could not test the mediator role of Ego orientation in the relationship between psychological needs satisfaction and sportsmanship due to insignificant correlations between the predictor and the mediator. We tested the mediator role of task orientation in this relationship. 
Table 3. Mediation estimates for task orientation in the relationship between the need of autonomy satisfaction and the five dimensions of sportsmanship

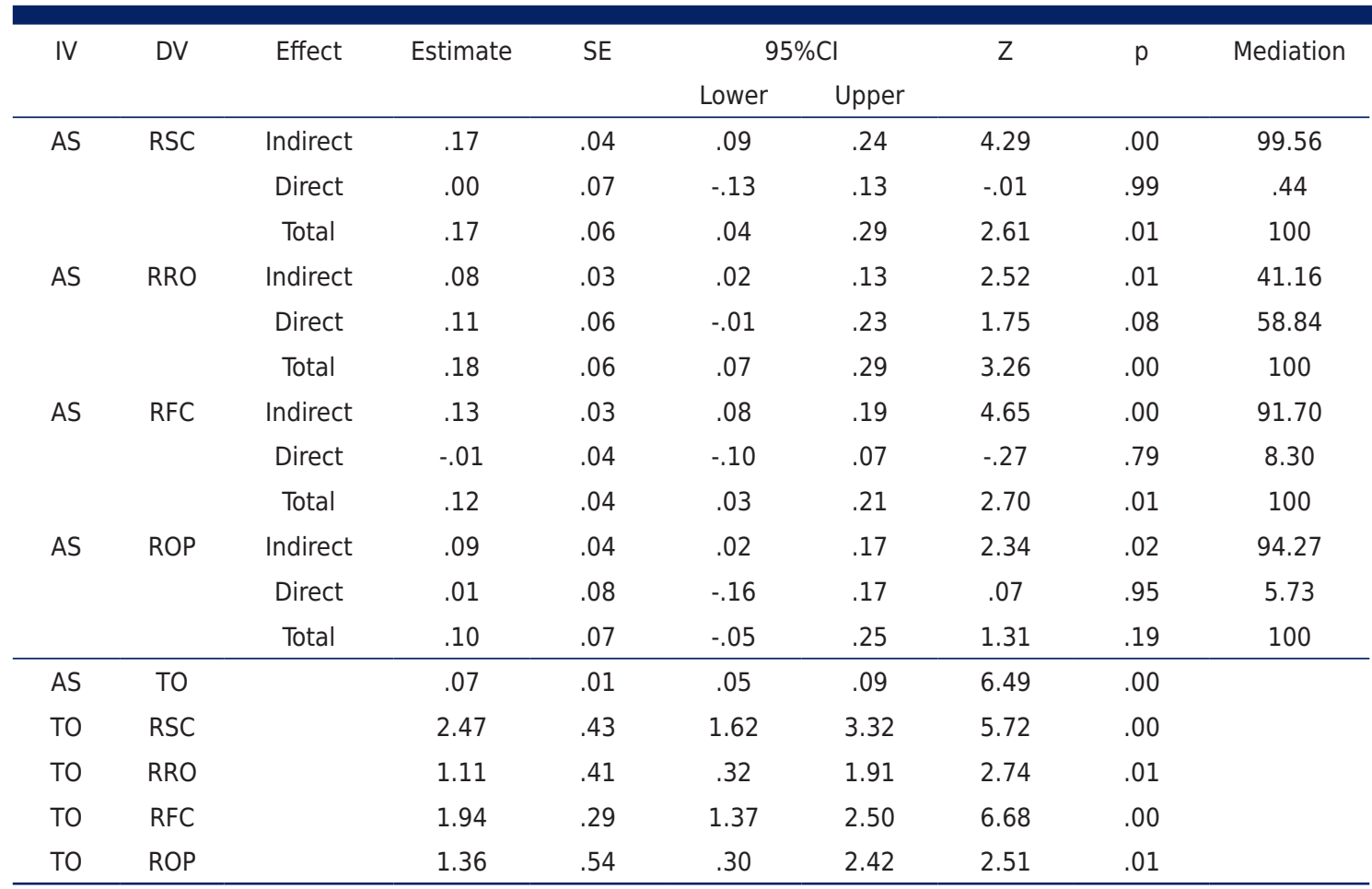

AS - Autonomy satisfaction, RSC - Respect for social conventions, RRO - Respect for rules and officials, RFC - Respect for full commitment, ROP - Respect for opponent, TO - Task orientation

It is observed that task orientation mediates the relationship between the need for autonomy satisfaction and certain dimensions of sportsmanship. Thus, the mediation percentage for respect for social conventions is $99.56 \%$, the mediation estimate being $\beta=.17$, CI95\% $(.09, .24), \mathrm{Z}=4.29, \mathrm{p}<.01$. The need for autonomy satisfaction is positively associated with task orientation, $\beta=.07$, CI95\% (.05, .09), $\mathrm{Z}=6.49, \mathrm{p}<.01$, and task orientation is positively associated with respect for social conventions, $\beta=2.47$, CI95\% $(1.62,3.32)$, $\mathrm{Z}=5.72, \mathrm{p}<.01$. Also, the percentage of mediation for respect for rules and officials is $41.16 \%$, the mediation estimate being $\beta=.08$, CI95\% $(.02, .13), Z=2.52, p<.01$. The need for autonomy satisfaction is positively associated with task orientation, $\beta=.07, \mathrm{CI} 95 \%$ (.05, $.09), \mathrm{Z}=6.49, \mathrm{p}<.01$, and task orientation is positively associated with respect for rules and officials, $\beta=1.11$, CI95\% $(.32,1.91), \mathrm{Z}=2.74, \mathrm{p}<.05$. The percentage of mediation for respect for full commitment is $91.70 \%$, the mediation estimate being $\beta=.13$, CI95\% $(.08, .19), \mathrm{Z}=4.65, \mathrm{p}<.01$. The need for autonomy satisfaction is positively associated with task orientation, $\beta=.07$, CI95\% (.05, .09), $\mathrm{Z}=6.49, \mathrm{p}<.01$, and task orientation is positively associated with respect for full commitment, $\beta=1.94$, CI95\% $(1.37,2.50)$, $\mathrm{Z}=6.68, \mathrm{p}<.01$. At the same time, the percentage of mediation for respect for opponents is $94.27 \%$, the mediation estimate being $\beta=.09$, CI95\% $(.02, .17), Z=2.34, p<.05$. The need for autonomy satisfaction is positively associated with task orientation, $\beta=.07$, CI95\% (. $05, .09), \mathrm{Z}=6.49, \mathrm{p}<.01$, and task orientation is positively associated with respect for opponents, $\beta=1.36$, CI95\% (.30, 2.42), $\mathrm{Z}=2.51, \mathrm{p}<.05$.

It is observed that task orientation mediates the relationship between the need for autonomy satisfaction and certain dimensions of sportsmanship. Thus, the mediation percentage for respect for social conventions is $99.56 \%$, the mediation estimate being $\beta=.17$, CI95\% $(.09, .24), \mathrm{Z}=4.29, \mathrm{p}<.01$. The need for autonomy satisfaction is positively associated with task orientation, $\beta=.07$, CI95\% (.05, .09), $\mathrm{Z}=6.49, \mathrm{p}<.01$, and task orientation is positively associated with respect for social conventions, $\beta=2.47$, CI95\% $(1.62,3.32)$, $\mathrm{Z}=5.72, \mathrm{p}<.01$. Also, the percentage of mediation for respect for rules and officials is 
$41.16 \%$, the mediation estimate being $\beta=.08$, CI95\% (.02, .13), $\mathrm{Z}=2.52, \mathrm{p}<.01$. The need for autonomy satisfaction is positively associated with task orientation, $\beta=.07$, CI95\% (.05, $.09), \mathrm{Z}=6.49, \mathrm{p}<.01$, and task orientation is positively associated with respect for rules and officials, $\beta=1.11$, CI95\% (.32, 1.91), $\mathrm{Z}=2.74, \mathrm{p}<.05$. The percentage of mediation for respect for full commitment is $91.70 \%$, the mediation estimate being $\beta=.13$, CI95\% $(.08, .19), Z=4.65, p<.01$. The need for autonomy satisfaction is positively associated with task orientation, $\beta=.07$, CI95\% (.05, .09), $\mathrm{Z}=6.49, \mathrm{p}<.01$, and task orientation is positively associated with respect for full commitment, $\beta=1.94$, CI95\% $(1.37,2.50)$, $\mathrm{Z}=6.68, \mathrm{p}<.01$. At the same time, the percentage of mediation for respect for opponents is $94.27 \%$, the mediation estimate being $\beta=.09$, CI95\% $(.02, .17), Z=2.34, p<.05$. The need for autonomy satisfaction is positively associated with task orientation, $\beta=.07$, CI95\% (. 05, .09), $\mathrm{Z}=6.49, \mathrm{p}<.01$, and task orientation is positively associated with respect for opponents, $\beta=1.36$, CI95\% (.30, 2.42), $Z=2.51, p<.05$.

Table 4. Mediation estimates for task orientation in the relationship between the need of competence satisfaction and the five dimensions of sportsmanship

\begin{tabular}{|c|c|c|c|c|c|c|c|c|c|}
\hline \multirow[t]{2}{*}{ IV } & \multirow[t]{2}{*}{ DV } & \multirow[t]{2}{*}{ Effect } & \multirow[t]{2}{*}{ Estimate } & \multirow[t]{2}{*}{$\mathrm{SE}$} & \multicolumn{2}{|c|}{$95 \% \mathrm{Cl}$} & \multirow[t]{2}{*}{ Z } & \multirow[t]{2}{*}{$p$} & \multirow[t]{2}{*}{ Mediation } \\
\hline & & & & & Lower & Upper & & & \\
\hline \multirow{2}{*}{ CS } & & Direct & .05 & .06 & -.07 & .17 & .86 & .39 & 27.43 \\
\hline & & Total & .19 & .06 & .07 & .31 & 3.18 & .00 & 100 \\
\hline \multirow{2}{*}{$\mathrm{CS}$} & & Direct & .15 & .06 & .03 & .26 & 2.51 & .01 & 70.10 \\
\hline & & Total & .21 & .05 & .10 & .31 & 3.86 & .00 & 100 \\
\hline CS & RFC & Indirect & .11 & .03 & .06 & .16 & 4.37 & .00 & 84.28 \\
\hline \multirow{2}{*}{$\mathrm{CS}$} & & Direct & .03 & .08 & -.13 & .18 & .33 & .74 & 24.37 \\
\hline & & Total & .11 & .07 & -.04 & .25 & 1.46 & .15 & 100 \\
\hline $\mathrm{CS}$ & TO & & .06 & .01 & .04 & .08 & 5.94 & .00 & \\
\hline TO & RSC & & 2.32 & .42 & 1.49 & 3.15 & 5.46 & .00 & \\
\hline TO & RRO & & 1.02 & .40 & .24 & 1.79 & 2.57 & .01 & \\
\hline TO & RFC & & 1.84 & .29 & 1.28 & 2.40 & 6.46 & .00 & \\
\hline TO & ROP & & 1.30 & .53 & .26 & 2.35 & 2.45 & .01 & \\
\hline
\end{tabular}

CS - Competence satisfaction, RSC - Respect for social conventions, RRO - Respect for rules and officials, RFC - Respect for full commitment ROP - Respect for opponent, TO - Task orientation

It is observed that task orientation mediates the relationship between the need for competence satisfaction and certain dimensions of sportsmanship. Thus, the mediation percentage for respect for social conventions is $72.57 \%$, the mediation estimate being $\beta=.14$, CI95\% (.07, $.21), \mathrm{Z}=4.02, \mathrm{p}<.01$. The competence need satisfaction is positively associated with task orientation, $\beta=.06$, CI95\% (.04, .08), $\mathrm{Z}=5.94, \mathrm{p}<.01$, and task orientation is positively associated with respect for social conventions, $\beta=2.32$, CI95\% $(1.49,3.15), Z=5.46$, $\mathrm{p}<.01$. Also, the percentage of mediation for respect for rules and officials is $29.90 \%$, the mediation estimate being $\beta=.06$, CI95\% (.01, .11), $Z=2.36, p<.05$. The need for competence satisfaction is positively associated with task orientation, $\beta=.06$, CI95\% $(.04, .08), Z=5.94$, $\mathrm{p}<.01$, and task orientation is positively associated with respect for rules and officials, $\beta=$ $1.02,95 \%$ CI $(.24,1.79), Z=2.57, p<.05$. The percentage of mediation for respect for full commitment is $84.28 \%$, the mediation estimate being $\beta=.11$, CI95\% (.06, .16), $Z=4.37$, $\mathrm{p}<.01$. The competence need satisfaction is positively associated with task orientation, $\beta=.06, \mathrm{CI} 95 \%(.04, .08), \mathrm{Z}=5.94, \mathrm{p}<.01$, and task orientation is positively associated with 
respect for full commitment, $\beta=1.84$, CI95\% (1.28, 2.40), $\mathrm{Z}=6.46, \mathrm{p}<.01$. At the same time, the percentage of mediation for respect for opponents is $75.63 \%$, the mediation estimate being $\beta=.08$, CI95\% (.01, .15), $\mathrm{Z}=2.27, \mathrm{p}<.05$. The need for competence satisfaction is positively associated with task orientation, $\beta=.06$, CI95\% $(.04, .08), Z=5.94, p<.01$, and task orientation is positively associated with respect for opponents, $\beta=1.30$, CI95\% (.26, 2.35), $\mathrm{Z}=2.75, \mathrm{p}<.05$.

Table 5. Mediation estimates for task orientation in the relationship between the need of relatedness satisfaction and the five dimensions of sportsmanship

\begin{tabular}{|c|c|c|c|c|c|c|c|c|c|}
\hline \multirow[t]{2}{*}{ IV } & \multirow[t]{2}{*}{ DV } & \multirow[t]{2}{*}{ Effect } & \multirow[t]{2}{*}{ Estimate } & \multirow[t]{2}{*}{ SE } & \multicolumn{2}{|c|}{$95 \% \mathrm{Cl}$} & \multirow[t]{2}{*}{ Z } & \multirow[t]{2}{*}{$\mathrm{p}$} & \multirow[t]{2}{*}{ Mediation } \\
\hline & & & & & Lower & Upper & & & \\
\hline \multirow[t]{3}{*}{ RS } & $\mathrm{RSC}$ & Indirect & .10 & .03 & .05 & .16 & 3.67 & .00 & 37.97 \\
\hline & & Direct & .17 & .05 & .07 & .27 & 3.21 & .00 & 62.03 \\
\hline & & Total & .27 & .05 & .17 & .37 & 5.43 & .00 & 100 \\
\hline \multirow[t]{3}{*}{ RS } & RRO & Indirect & .05 & .02 & .01 & .10 & 2.30 & .02 & 29.66 \\
\hline & & Direct & .13 & .05 & .03 & .23 & 2.55 & .01 & 70.34 \\
\hline & & Total & .18 & .05 & .09 & .27 & 3.95 & .00 & 100 \\
\hline \multirow[t]{3}{*}{ RS } & RFC & Indirect & .10 & .02 & .06 & .14 & 4.45 & .00 & 82.89 \\
\hline & & Direct & .02 & .04 & -.05 & .09 & .57 & .57 & 17.11 \\
\hline & & Total & .12 & .04 & .05 & .19 & 3.32 & .00 & 100 \\
\hline $\mathrm{RS}$ & TO & & .05 & .01 & .04 & .07 & 6.24 & .00 & \\
\hline TO & RSC & & 1.89 & .42 & 1.07 & 2.70 & 4.54 & .00 & \\
\hline TO & RRO & & .99 & .40 & .21 & 1.77 & 2.48 & .01 & \\
\hline TO & RFC & & 1.83 & .29 & 1.27 & 2.39 & 6.36 & .00 & \\
\hline
\end{tabular}

RS - Relatedness satisfaction, RSC - Respect for social conventions, RRO - Respect for rules and officials, RFC - Respect for full commitment, ROP - Respect for opponent, TO - Task orientation

It is observed that task orientation mediates the relationship between the need for relatedness satisfaction and certain dimensions of sportsmanship. Thus, the mediation percentage for respect for social conventions is $37.97 \%$, the mediation estimate being $\beta=.10$, CI95\% (.05, .16), $\mathrm{Z}=3.67, \mathrm{p}<.01$. The need for relatedness satisfaction is positively associated with task orientation, $\beta=.05$, CI95\% $(.04, .07), \mathrm{Z}=6.24, \mathrm{p}<.01$, and task orientation is positively associated with respect for social conventions, $\beta=1.89$, CI95\% $(1.07,2.70), Z=4.54$, $\mathrm{p}<.01$. Also, the percentage of mediation for respect for rules and officials is $29.66 \%$, the mediation estimate being $\beta=.05$, CI95\% $(.01, .10), Z=2.30, p<.05$. The need for relatedness satisfaction is positively associated with task orientation, $\beta=.05$, CI95\% (.04, .07), Z $=6.24$, $\mathrm{p}<.01$, and task orientation is positively associated with respect for rules and officials, $\beta=.99$, CI95\% $(.21,1.77), Z=2.48, p<.05$. The percentage of mediation for respect for full commitment is $82.89 \%$, the mediation estimate being $\beta=.10$, CI95\% (.06, .14), $Z=4.45$, $\mathrm{p}<.01$. The need for relatedness satisfaction is positively associated with task orientation, $\beta=.05, \mathrm{CI} 95 \%(.04, .07), \mathrm{Z}=6.24, \mathrm{p}<.01$, and task orientation is positively associated with respect for full commitment, $\beta=1.83$, CI95\% (1.27, 2.39), $Z=6.46, p<.01$.

\section{DISCUSSION}

The obtained results showed, first of all, that the satisfaction of basic psychological needs is associated with sportsmanship, but only to a small extent, so that only the need for relatedness satisfaction is a significant predictor for two dimensions of sportsmanship, respect for social conventions and respect for opponents.

Mediation analyses have shown that task orientation mediates the relationship between the need for autonomy and the need for competence satisfaction, on the one hand, and 
four of the dimensions of sportsmanship, on the other hand: respect for social conventions, respect for rules and officials, respect for full commitment, and respect for opponents, as well as the relationship between the need for relatedness satisfaction and three of these dimensions: respect for social conventions, respect for rules and officials, and respect for full commitment.

It is possible that these results are due to the fact that sports students recorded high levels of satisfaction of all three basic psychological needs, despite the fact that the data were collected during the COVID-19 pandemic. The need for relatedness satisfaction was positively associated with respect for social conventions and respect for opponents, which clearly demonstrates that sports students who have the quality of interpersonal relationships and are affiliated to a group or a club in which they feel accepted and appreciated will tend to behave with greater sportsmanship attitude towards the rules and towards the opponents.

Task orientation is in itself an orientation towards personal growth and achieving experience, and for this reason it contributes to the development of positive sports attitudes, such as respect for social conventions, respect for rules and officials, respect for full commitment, and respect for opponents. The students in the research group are integrated in sports clubs where they are trained by specialists who pay special attention to their moral development. The transition from aggressive to positive competition is an important step in training and coaching athletes, whether they play team or individual sports. Thus, basic psychological needs satisfaction contributes to increasing task orientation, which in turn contributes to increasing sportsmanship. Sportsmanship can be learned if students are trained to follow the rules, to respect the authorities and opponents, but also to show full involvement in the training and competitions in which they participate. Coaches, teachers and parents are the ones who contribute the most to the basic psychological needs satisfaction of young people: they are inspired to focus more on personal development, on the satisfaction of participating in important competitions and less on actual gain.

Tian, Zhang and Huebner obtained similar results in a study conducted with the participation of 801 Chinese adolescents [54]. The researchers found that basic psychological needs satisfaction has direct effects on prosocial behaviour. Thus, the need for relatedness and competence satisfaction were associated with prosocial behaviours, while low need for relatedness satisfaction, but not for competence or autonomy is associated with antisocial behavior. Kuzucu and Șimșek analysed the relationship between basic psychological needs satisfaction and aggression among 466 Turkish adolescents, noting that the frustration of these needs leads not only to aggression but also to the inability to set clear life goals and make decisions about their own career [55]. Haralabos examined the effect of task and ego orientation on athletic identity and antisocial behaviour of 156 students and athletes. Their results showed that both ego and task orientations affect antisocial behaviour [56].

Psychological training is a part of the general training of an athlete, which is found in all components of sports training [57]. Many studies have shown that what makes the difference in winning is the character, the motivation to participate and the intelligence as the basic components of the athlete's personality $[58,59]$.

\section{CONCLUSIONS}

The aim of this study was to examine the relationships among basic psychological needs satisfaction, goal orientations and sportsmanship. These three constructs are essential in the development of athletes because they are fundamental elements of the development of morale and proper conduct for the sports environment. They are also important in activating the motivational mechanisms of athletes. The fact that goal orientation affects sportsmanship 
gives a major responsibility to coaches and instructors who have a huge contribution to the training of athletes. Thus, based on these results, specific training programs can be developed that focus on developing the intrinsic motivation of athletes and task orientation in general. The differentiation between competition for results and competition for experimentation must be very well understood by students, so that participation in competitions does not focus exclusively on obtaining high scores, but especially on obtaining constructive personal development experiences. Attitude formation, on which the character is structured and developed, implies specific methods and techniques that can be developed through training [60].

\section{REFERENCES}

[1] Ryan R, Deci E. Self-determination theory and the facilitation of intrinsic motivation, social development, and wellbeing. Am Psychologist. 2020;55:68-78. https://doi.org/10.1037/0003-066X.55.1.68

[2] Buhaș SD, Stance L. The Relationship between Personality and Physical Activity. Geosport Soc. 2017;7(2):72-77.

[3] Reinboth M, Duda J. Perceived motivational climate, need satisfaction and indices of well-being in team sports: A longitudinal perspective. Psychol Sport Exerc. 2006;7:269-286. https://doi.org/10.1016/j.psychsport.2005.06.002

[4] Standage M, Duda JL, Ntoumanis N. A model of contextual motivation in physical education: Using constructs from self-determination and achievement goal theories to predict physical activity intentions. J Educ Psychol. 2003;95(1):97. https://doi.org/10.1037/0022-0663.95.1.97

[5] Cristea D.I., Motoc I., Pop A.C. Aspects regarding the integration of children with special educational needs through participation in physical education. Balt J Health Phys Act. 2020;12(1). https://doi.org/10.29359/BJHPA.12.Spec.Iss1.09

[6] Sheldon KM, Zhaoyang R, Williams, MJ. Psychological Need Satisfaction, and Basketball Performance. Psychol Sport Exerc. 2013;14:675-681. https://doi.org/10.1016/j.psychsport.2013.05.006

[7] Deci EL, Ryan, RM. Overview of self-determination theory. The Oxford Handbook of Human Motivation. 2013 , 85.

[8] Dragoș P, Lucaciu G, Dinis I, Stef Gavriș M, Szabo-Alexi P, Buhaș S. Concepts Concerning the Content of Children's Training in Some Sport Games. Proceedings of the 4th International Conference of the Universitaria Consortium (ICU 2018): The Impact of Sport and Physical Education Science on Today's Society. 2018, 67-72.

[9] Hodge K, Lonsdale C. Prosocial and antisocial behavior in sport: The role of coaching style, autonomous vs. controlled motivation, and moral disengagement. J Sport Exerc Psychol. 2011;55(4):527. https://doi.org/10.1123/jsep.33.4.527

[10] Deci EL, Ryan, RM. The "what" and the "why" of goal pursuits: Human needs and the self-determination of behavior Psycholog Inq. 2000;11:227-268. https://doi.org/10.1207/S15327965PLI1104_01

[11] Ryan RM, Deci EL, Grolnick WS, La Guardia JG. The significance of autonomy and autonomy support in psychological development and psychopathology. In: D. Cicchetti \& C. D. (Eds.), Developmental psychopathology: Theory and methods (2 ed., Vol. 1). New York: Wiley; 2006, 795-849. https://doi.org/10.1002/9780470939383.ch20

[12] Van der Elst T, Van den Broeck A, De Witte H, De Cuyper N. The mediating role of psychological need frustration in the relationship between job insecurity and work-related well-being. Work and Stress. 2012;26:252-271. https://doi. org/10.1080/02678373.2012.703900

[13] Herman GV, Banto N, Caciora T, Ungureanu M, Furdui S, Grama V, Buhas R, Buhas S. Tourism in Bihor County, Romania. Trends and Prospects. Folia Geogr. 2020;62:87-105

[14] Klassen RM, Perry NE, Frenzel AC. Teachers' relatedness with students: An underemphasized component of teachers basic psychological needs. J Educ Psychol. 2012;104:150-165. https://doi.org/10.1037/a0026253

[15] Ahmad I, Vansteenkiste M, Soenens B. The relations of Arab Jordanian adolescents' perceived maternal parenting to teacher-rated adjustment and problems: The intervening role of perceived need satisfaction. Develop Psychol. (in press). https://doi.org/10.1037/a0027837

[16] Reis HT, Sheldon KM, Gable SL, Roscoe J, Ryan RM. Daily well-being: The role of autonomy, competence, and relatedness. Personal Soc Psychol Bull. 2000;26:419-435. https://doi.org/10.1177/0146167200266002

[17] Zadarko E, Zbigniew B, Szabo-Alexi P, et al. Physical Education and Students' Health Promotion Platform as an Element of European Union's Health Strategy Against the Level of Cardiorespiratory Fitness of Students From Poland, Slovakia, Romania. Studia Universitatis Babes-Bolyai, Educatio Artis Gymnasticae. 2011;56(3):107-116.

[18] Ryan RM, Bernstein JH, Brown KW. Weekends, work, and well-being: Psychological need satisfactions and day of the week effects on mood, vitality, and physical symptoms. J Soc Clin Psychol. 2010:29;95-122. https://doi.org/10.1521/ jscp.2010.29.1.95

[19] Dragos P, Lucaciu G, Trifa I, Mirela Stef Gavris M, Szabo-Alexi P, Buhas S. Aspects Regarding the Influence of Communication on the Motivation of Employees in Some Sports Organizations. Proceedings of the 4th International Conference of the Universitaria Consortium (ICU 2018): The Impact of Sport and Physical Education Science on Today's Society; 2018, 73-77.

[20] Brândescu S. Analysis of specialist opinions about the problem of selection in the game of football for children 6-8 years of age. Timisoara Phys Educ Rehabil J. 2015;7(14):46-50. https://doi.org/10.1515/tperj-2015-0007

[21] Bartholomew KJ, Ntoumanis N, Ryan RM, Thogersen-Ntoumani C. Psychological need thwarting in the sport context: Assessing the darker sides of athletic experience. J Sport Exerc Psychol. 2011;33:75-102. https://doi.org/10.1123/ jsep.33.1.75

[22] Stebbings J, Taylor I M, Spray CM, Ntoumanis N. Antecedents of perceived coach interpersonal behaviors: The coaching environment and coach psychological well- and ill-being. J Sport Exerc Psychol. 2012;34:481-502. https:// doi.org/10.1123/jsep.34.4.481 
[23] Joussemet M, Vitaro F, Barker ED, Coté S, Nagin D, Zoccolillo M, Tremblay RE. Controlling parenting and physical aggression during elementary school. Child Develop. 2008;79:411-425. https://doi.org/10.1111/j.14678624.2007.01133.x

[24] Thogersen-Ntoumani C, Ntoumanis N, Nikitaras N. Unhealthy weight control behaviours in adolescent girls: a process model based on self-determination theory. Psychol Health. 2010;25:535-550. https://doi.org/10.1080/08870440902783628

[25] Sebire SJ, Standage M, Vansteenkiste M. Examining intrinsic versus extrinsic exercise goals: Cognitive, affective, and behavioral outcomes. J Sport Exerc Psychol. 2009;31:189-210. https://doi.org/10.1123/jsep.31.2.189

[26] Duriez B, Vansteenkiste M, Soenens B, De Witte H. The social costs of extrinsic relative to intrinsic goal pursuits: Their relation with social dominance and racial and ethnic prejudice. J Personal. 2007;75:757-782. https://doi. org/10.1111/j.1467-6494.2007.00456.x

[27] Vansteenkiste M, Niemiec CP, Soenens B. "The development of the five mini-theories of self-determination theory: an historical overview, emerging trends, and future directions", Urdan, T.C. and Karabenick, S.A. (Ed.) The Decade Ahead: Theoretical Perspectives on Motivation and Achievement (Advances in Motivation and Achievement, Vol. 16 Part A), Emerald Group Publishing Limited, Bingley; 2010, 105-165. https://doi.org/10.1108/S0749-7423(2010)000016A007

[28] Donahue EG, Miquelon P, Vaiois P, Goulet C, Buist A, Vallerand RJ. A motivational model of performance-enhancing substance use in elite athletes. J Sport Exerc Psychol. 2006;28:511-520. https://doi.org/10.1123/jsep.28.4.511

[29] Deci EL, Ryan RM. Intrinsic motivation and self-determination in human behavior. New York: Plenum; 1985. https:// doi.org/10.1007/978-1-4899-2271-7

[30] Ryan RM, Lynch JH. Emotional autonomy versus detachment: Revisiting the vicissitudes of adolescence and young adulthood. Child Develop. 1989;60:340-356. https://doi.org/10.1111/j.1467-8624.1989.tb02720.x

[31] Vansteenkiste M, Soenens B, Van Petegem S, Wuyts D, Duriez B. The relation between degree and style of prohibition and adolescent internalisation and oppositional defiance. (in press); 2012.

[32] Van Petegem S, Beyers W, Vansteenkiste M, Soenens B. Psychological reactance as an explaining mechanism for adolescent rebellion: Associations with autonomy, parenting, and psychosocial functioning. Paper presented at the 15th European Conference on Developmental Psychology (ECDP), Bergen, Norway; 2011.

[33] National Collegiate Athletic Association. Report on the sportsmanship and fan behavior summit; 2003: Retrieved May 30, 2021, from http://www.ncaa.org/sportsmanshipFanBehavior/report.pdf.

[34] Shields DLL, Bredemeier BJL. Character development and physical activity. Champaign, IL: Human Kinetics: 1995.

[35] Stornes T, Bru E. Sportspersonship and Perceptions of Leadership: An Investigation of Adolescent Handball Players' Perception of sportspersonship and Associations with Perceived Leadership. Eur J Sport Sci. 2002;2(6):1-15. https:// doi.org/10.1080/17461391.2002.10142577

[36] Cremades JG, Tashman LS. (Eds.). Becoming a sport, exercise, and performance psychology professional: A global perspective. Psychology Press; 2014. https://doi.org/10.4324/9780203093184

[37] Tel M. Türk toplum yaşantısında Fair Play. Int J Sci Culture Sport. 2014;1:694-704. https://doi.org/10.14486/IJSCS139

[38] Toohey K, Veal AJ. The Olympic Games: A Social Science Perspective. UK: Cabi Publishing. Library of Congress Cataloguing; 2000.

[39] Sleek S. Competition: Who's the real opponent? APA Monitor; 1996:8. https://doi.org/10.1037/e529752010-015

[40] Raspberry W. Too strict a standard on cheating? Washington Post; 1998 June 22p. A21.

[41] Stoll SK, Beller JM. Can character be measured? J Phys EducRecreat Dance. 1998:69(1), 19-24. https://doi.org/10. 1080/07303084.1998.10605042

[42] Bandura A. Social foundations of thought and action: A social cognitive theory. Englewood Cliffs, NJ: Prentice-Hall; 1986.

[43] Bandura, A. Social-cognitive theory of moral thought and action. In W. M. Kurtines \& J. L. Gewirtz (Eds.), Handbook of moral behavior and development Hillsdale, Vol. 1. NJ: Erlbaum; 1996, 45-103.

[44] Rest JR. Moral development: Advances in research and theory. New York: Praeger; 1986.

[45] Bredemeier BJ, Shields DL. Applied ethics and moral reasoning in sport. In J. Rest \& D. Narvaez (Eds.), Moral development in the professions: Psychology and applied ethics. Hillsdale, NJ: Erlbaum; 1994, $173-187$.

[46] Bredemeier BJ, Shields DL. Moral development and children's sport. In F. L. Smoll \& R. E. Smith (Eds.), Children and youth in sport: A biopsychosocial perspective. Madison, WI: Brown \& Benchmark; 1996, $381-401$.

[47] Olszewski-Strzyżowski DJ. European societies' access to sport-the European Union actions. GeoSport for Society. 2018;9(2):71-81.

[48] Gagne, M. The role of autonomy support and autonomy orientation in prosocial behavior engagement. Motivat Emotion. 2003;27:199-223.

[49] Vallerand RJ, Brière NM, Blanchard C, Provencher P. Development and validation of the Multidimensional Sportspersonship Orientation Scale (MSOS). Journal of Sport and Exercise Psychology; 1997:19, 197-206. https:// doi.org/10.1123/jsep.19.2.197

[50] IBM Corp. Released 2016. IBM SPSS Statistics for Windows, Version 24.0. Armonk, NY: IBM Corp.

[51] The jamovi project jamovi (Version 1.6) [Computer Software]; 2021. Retrieved from https://www.jamovi.org

[52] Baron RM, Kenny DA. The Moderator-Mediator Variable Distinction in Social Psychological Research: Conceptual, Strategic, and Statistical Considerations. J Personal Soc Psychol. 1986;51(6):1173-1182. https://doi.org/10.1037/00223514.51.6.1173

[53] Hayes A F. Beyond Baron and Kenny: Statistical Mediation Analysis in the New Millennium. Communication Monographs. 2009;76(4):408-420. https://doi.org/10.1080/03637750903310360

[54] Tian L, Zhang X, Huebner ES. The effects of satisfaction of basic psychological needs at school on children's prosocial behavior: The mediating role of school satisfaction. Fronti Psychol. 2018;9:548. https://doi.org/10.3389/ fpsyg.2018.00548

[55] Kuzucu Y, Șimșek OF. Self-Determined Choices and Consequences: The Relationship Between Basic Psychological Needs Satisfactions and Aggression in Late Adolescents. J General Psychol. 2013;140(2):110-129. https://doi.org/1 $0.1080 / 00221309.2013 .771607$ 
[56] Haralabos K, Ioannis A, Evaggelos B, Athanasios L. The effect of task and ego orientation to athletic identity and antisocial behavior of students and athletes. J Human Sport Exerc. 2016;11(2):311-318. https://doi.org/10.14198/ jhse.2016.112.04

[57] Barbu, D. Aspecte ale pregătirii psihologice în jocul de fotbal [Aspects of psychological training in the game of football]. Craiova: Editura Universitaria; 2002.

[58] Barbu D, Stoica D, Cosma A. Important aspects regarding the psychological training in juniors' football players. 5TH International Multidisciplinary Scientific Conference on Social Sciences and Arts SGEM. 2018. https://doi. org/10.5593/sgemsocial2018/3.4/S13.053

[59] Predoiu R. Psihologia sportivă și făuritorii performanței [Sports psychology and performance creators]. Bucharest: Editura Hoffman; 2021.

[60] Barbu D, Forțan C, Stoica D. Psychological Characteristics of Leading the Junior Footballers' Teaching - Learning Process. Bulletin of the Transilvania University of Brasov. Series IX: Sciences of Human Kinetics. 2020;13(62). https:// doi.org/10.31926/but.shk.2020.13.62.2.2 